\title{
Potential of soil cover with plastic film for the setting of sweet orange orchards
}

\author{
Camilla de Andrade Pacheco ${ }^{1}$, Eduardo Augusto Girardi², Samuel de Moura Silva ${ }^{3}$, \\ José Adelmo Souto Gueiros ${ }^{4}$, Renato Beozzo Bassanezi ${ }^{5}$
}

\begin{abstract}
Soil cover with plastic film is a practice used to optimize the agronomic performance of different crops, but its behavior in the citrus growing conditions of Brazil remains unknown. Five experiments in commercial orchards located in the state of São Paulo, in rainfed or irrigated systems, were carried out to evaluate the effect of soil cover with plastic film (white/black or silver/ black color) on the vegetative growth and initial production of sweet orange trees up to 3.5 years after planting. In each location and experiment, completely randomized design was used, with four to ten replicates and five to twelve useful trees per plot. Considering the set of results, soil cover with plastic film increased the average canopy volume by $27 \%$ and the average production per tree by $33 \%$ compared to control trees without plastic cover. The positive effect of plastic cover was observed until the third year of its application, gradually decreasing with its degradation. In general, greater relative increases were observed in variables evaluated with the use of plastic cover in rainfed experiments than irrigated ones, while the effect of white/black either silver/black films was similar.
\end{abstract}

Index terms: Citrus sinensis, plasticulture, production system, planting, plant growth.

\section{Potencial da cobertura de solo com filme plástico no estabelecimento de pomares de laranjeira-doce}

Corresponding author: camilla.pacheco@fundecitrus. com.br

Received: October 27, 2020 Accepted: February 12, 2021

Copyright: All the contents of this journal, except where otherwise noted, is licensed under a Creative Commons Attribution License.

\section{(cc) $\mathbf{E Y}$}

Resumo - A cobertura do solo com filme plástico é uma prática utilizada para otimizar o desempenho agronômico de diferentes culturas, mas não se conhece seu comportamento nas condições de cultivo de citros no Brasil. Cinco experimentos em pomares comerciais localizados no Estado de São Paulo, em sequeiro ou irrigados, foram realizados para avaliar o efeito da cobertura de solo com filme plástico (cor branca/preta ou prata/preta) no crescimento vegetativo e na produção inicial de laranjeiras-doces até 3,5 anos após o plantio. Em cada localidade e experimento, utilizou-se delineamento inteiramente casualizado, com quatro a dez repetições e de cinco a doze plantas úteis por parcela. Considerando-se o conjunto de resultados, a cobertura de solo com filme plástico aumentou, em média, $27 \%$ o volume de copa e $33 \%$ a produção média por planta em relação à testemunha sem cobertura. O efeito positivo da cobertura foi observado até o terceiro ano de sua aplicação, reduzindo-se gradativamente com sua degradação. Em geral, observaram-se maiores incrementos relativos nas variáveis avaliadas com o uso da cobertura nos experimentos de sequeiro em relação aos irrigados, enquanto o efeito de filmes nas cores branca/preta e prata/preta foi similar. Termos para indexação: Citrus sinensis, plasticultura, sistema de produção, plantio, crescimento de planta.

${ }^{1} \mathrm{PhD}$, Postdoctoral Researcher, Fund for Citrus Protection - Fundecitrus, Araraquara-SP, Brazil. E-mail: camilla.pacheco@fundecitrus.com.br (ORCID 0000-0001-8067-3181)

${ }^{2} \mathrm{PhD}$, Researcher, Embrapa Cassava and Fruits, Cruz das Almas-BA, Brazil. E-mail: eduardo.girardi@embrapa.br( ${ }^{\text {(ORCID 0000-0003-4839-5227) }}$ ${ }^{3}$ Agronomist, Research Assistant, Fund for Citrus Protection - Fundecitrus, Araraquara-SP, Brazil. E-mail: samuel.silva@fundecitrus.com.br (ORCID 0000-0002-4898-7479)

${ }^{4}$ Chemist, Technical Representative, Electro Plastic, São Paulo-SP, Brazil. E-mail: adelmogueiros.repres@gmail.com ${ }^{(0 R C I D}$ 0000-0001-5825-5266) ${ }^{5} \mathrm{PhD}$, Researcher, Fund for Citrus Protection - Fundecitrus, Araraquara, SP, Brazil. E-mail: renato.bassanezi@fundecitrus.com.br ${ }^{(\mathrm{RCID}}$ 00000003-4973-6708) 


\section{Introduction}

Citrus orchards have an establishment phase that goes from planting to initial commercial fruit production, which generally lasts three years (DE NEGRI et al., 2005). Due to the continued need to reduce production costs and anticipate revenues, accelerating the initial growth of sweet orange trees has become an important and challenging issue, especially after the presence of the Huanglongbing disease (HLB or "ex-greening") in the orchards of the citrus belt in São Paulo and Triângulo/Southwestern regions of Minas Gerais since 2004 (COLETTA-FILHO et al., 2004). Among the different cultural practices that can contribute to this objective, the use of soil cover with plastic films is highlighted, which can be water-repellent or permeable, white or colored, permanent or photo/ biodegradable, reflective or not, and whose application interferes with horticultural and phytosanitary aspects in the orchard (SHIMAZAKI; NESUMI, 2016; JIANG et al., 2014; KASIRAJAN; NGOUAJIO, 2012).

With regard to horticultural aspects, the use of plastic film cover decreases soil thermal amplitude, maintains soil moisture, controls weed and allows for a more efficient use of nutrients applied to soil by plants, factors that together increase productivity in different crops (KASIRAJAN; NGOUAJIO, 2012). In addition, plastic film cover changes not only the amount of light reflected by the soil, but also its quality, which can affect nonvisible light and, consequently, plant growth (TARARA, 2000). Dark colored plastic covers, such as blue and black, provide increase in soil temperature, implying greater vegetative growth (KUNIGA et al., 2019).

On the other hand, the phytosanitary aspect refers, essentially, to the repellency or disorientation of pest insects or vectors of pathogens with daytime flight, making it difficult for them to find host plants when using reflective plastic covers (GREER; DOLE, 2003). Particularly in citrus, the use of metallized plastic cover reduced by almost $50 \%$ the number of shoots infested with the Asian citrus psyllid (Diaphorina citri) and its capture on yellow sticky cards, decreasing the incidence of HLB compared with plots without plastic film cover (CROXTON; STANSLY, 2014).

Due to a higher frequency of vegetative flushes, young citrus trees are more vulnerable to infection by diseases such as HLB, citrus variegated chlorosis and citrus canker (BASSANEZI et al., 2016). In the case of HLB, citrus trees infected within four years of planting lose their productive capacity in one or two years, while adult trees lose $50 \%$ of their productive capacity only four to five years after showing the first symptoms of the disease (BASSANEZI, 2018). Therefore, it is interesting to promote the rapid growth and bearing of citrus trees in newly planted orchards.

Since little is known about the behavior and potential of soil cover with plastic film in the establishment of orange orchards in the citrus growing conditions of Brazil, the present work reports the vegetative growth and initial production of sweet orange trees managed with different plastic covers in four locations in the state of São Paulo.

\section{Material and methods}

Five different experiments were installed in commercial orange farms located in the state of São Paulo, three in non-irrigated plots and two in drip-irrigated plots, with the detailed description of each experiment presented in Table 1. In all locations, the climate was classified as Aw by the modified Köppen system (SETZER, 1966), that is, tropical with dry winter, average temperature of the coldest month $\geq 18{ }^{\circ} \mathrm{C}$, average temperature of the warmest month $\geq 22^{\circ} \mathrm{C}$, total precipitation in the driest month $<60 \mathrm{~mm}$ and total annual precipitation $<2,500 \mathrm{~mm}$ (ROLIM et al., 2007). Additionally, the monthly rainfall in each location was recorded throughout the assessment period (Figure 1).

Soils were classified in each evaluated location according to Rossi (2017): Typical dystrophic Red-Yellow Latosol, A moderate, medium texture, alic and wavy to smooth relief phase (Gavião Peixoto/SP - experiment I); Red-Yellow Argisol, A moderate, medium/clayey texture and wavy relief phase (Bariri/SP - experiments II and III); Eutrophic Red-Yellow Argisol, A moderate, sandy/ medium texture and smooth to wavy relief phase (Itápolis/ SP - experiment IV); and Typical dystrophic Red Latosol, A moderate, medium/clayey texture, alic and wavy relief phase (Santa Rosa de Viterbo/SP - experiment V). 


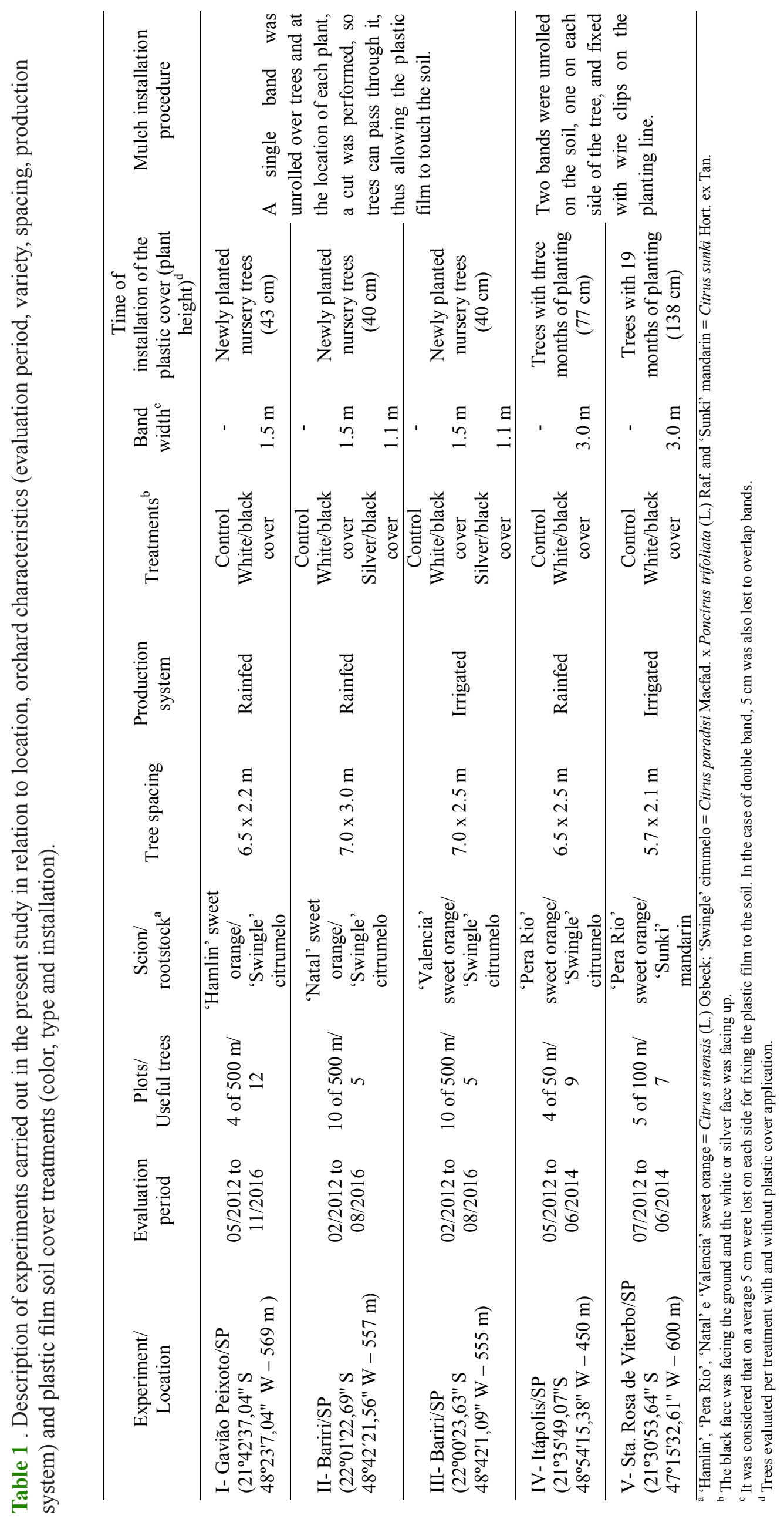




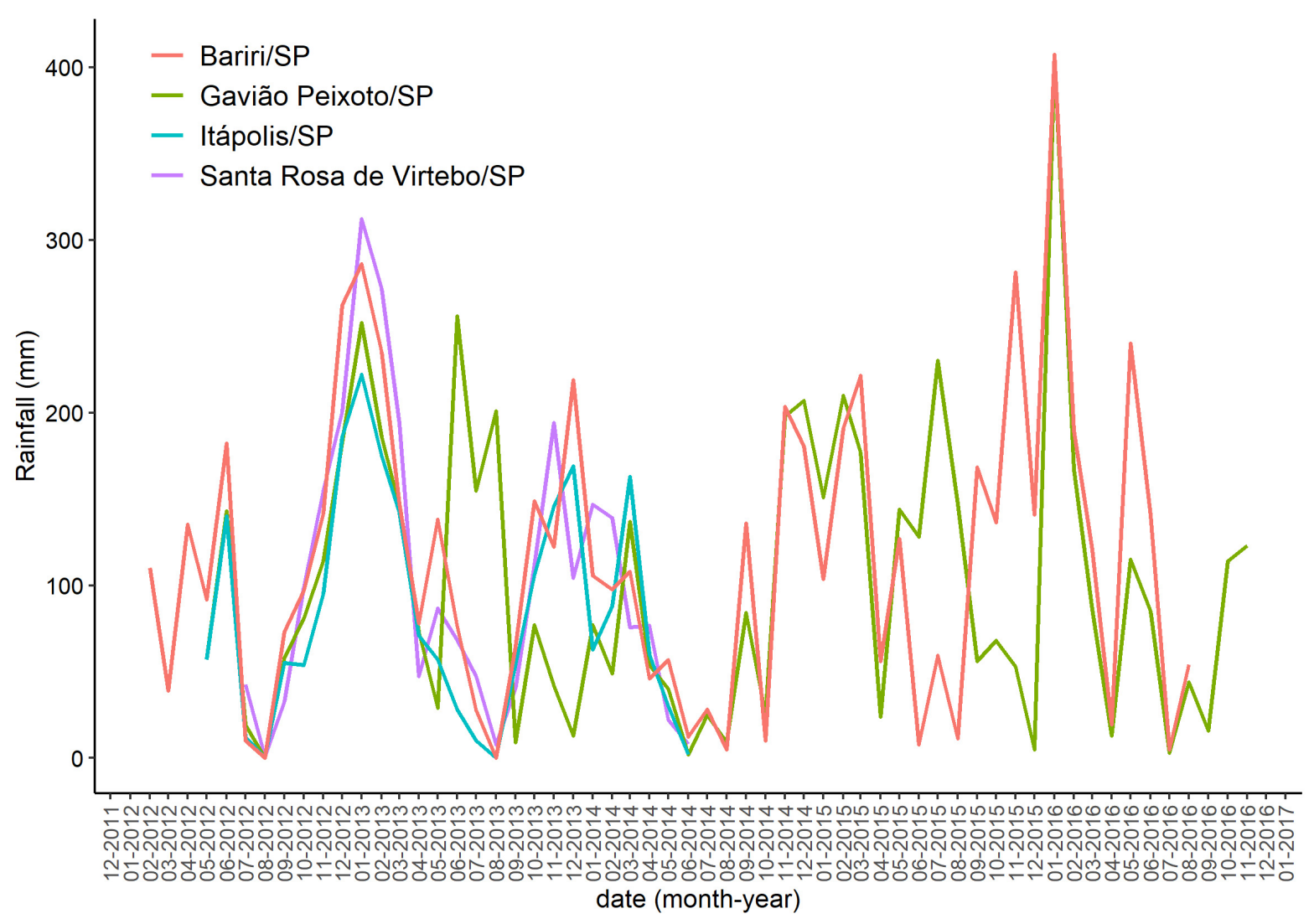

Figure 1. Monthly rainfall in the locations where experiments were conducted: Gavião Peixoto/SP (experiment I), Bariri/ SP (experiments II and III), Itápolis/SP (experiment IV) and Santa Rosa de Viterbo/SP (experiment V). Data related to the evaluation period in each location (Table 1) were obtained from rain gauge installed on each farm, except for Santa Rosa de Viterbo/SP, which was obtained from the weather station of the Integrated Center for Agrometeorological Information (http://www.ciiagro.sp.gov.br/) installed the closest to the location.

In each location, cultural practices carried out were those usually recommended for citrus cultivation in the state of São Paulo (MATTOS Jr. et al., 2014). Fertilizers, doses and application splitting used for soil and leaf fertilization varied in each experiment according to recommendations adopted by each farm; however, they were the same in plots with and without plastic cover within each location, except for plot with plastic film cover without irrigation in the Bariri experiment, in which slow-release fertilizers were applied, while in irrigated plots, fertilization was carried out by fertigation (Table 1).

The plastic films used in experiments were biodegradable based on linear low-density polyethylene (LLDPE) with additives, not light diffusers, not even PAR light transmitters, with tensile strength $\left(\mathrm{kgf} / \mathrm{cm}^{2}\right)$ of machine direction $(\mathrm{MD}) \geq 163$ and of transverse direction (TD) $\geq 163$, falling dart impact $(\mathrm{g}) \geq 80$, elongation (\%) of $\mathrm{TD} \geq 200$ and of $\mathrm{MD} \geq 200$, density $\left(\mathrm{g} / \mathrm{cm}^{3}\right)$ from 0.918 to 0.925 and durability of 24 months (EcoMulching, Electro Plastic, São Paulo, SP). According to each experiment (Table 1), films with different colors were used on the exposed surface in relation to the buried surface, which was always black, evaluating film (white/black color) with
$1.60 \mathrm{~m}$ in width and $40 \mu \mathrm{m}$ in thickness and film (silver/ black color) with $1.20 \mathrm{~m}$ in width and $35 \mu \mathrm{m}$ in thickness.

For the installation of the plastic cover, soil in the planting line was leveled with leveling harrow or moldboard plow with rod and finished with hoe before applying the plastic film cover. In plots with newly planted nursery trees, a single band of the film was unrolled over trees and, at the location of each tree, a cut was performed for the tree to pass through it, thus allowing the plastic film to touch the soil (Figures 2A and 2B). In plots with larger trees, two film bands were unrolled on the soil one on each side of the tree and fixed with wire clips on the planting line (Figures 2C and 2D). Plastic films were manually fixed to the soil with the aid of a hoe, except for experiment I, in which a rear blade coupled to a tractor (Massey Ferguson 283, $4 \times 4$ traction in $3^{\text {rd }}$ low gear) was used, covering with soil the first $5 \mathrm{~cm}$ from the sides of the plastic cover. 

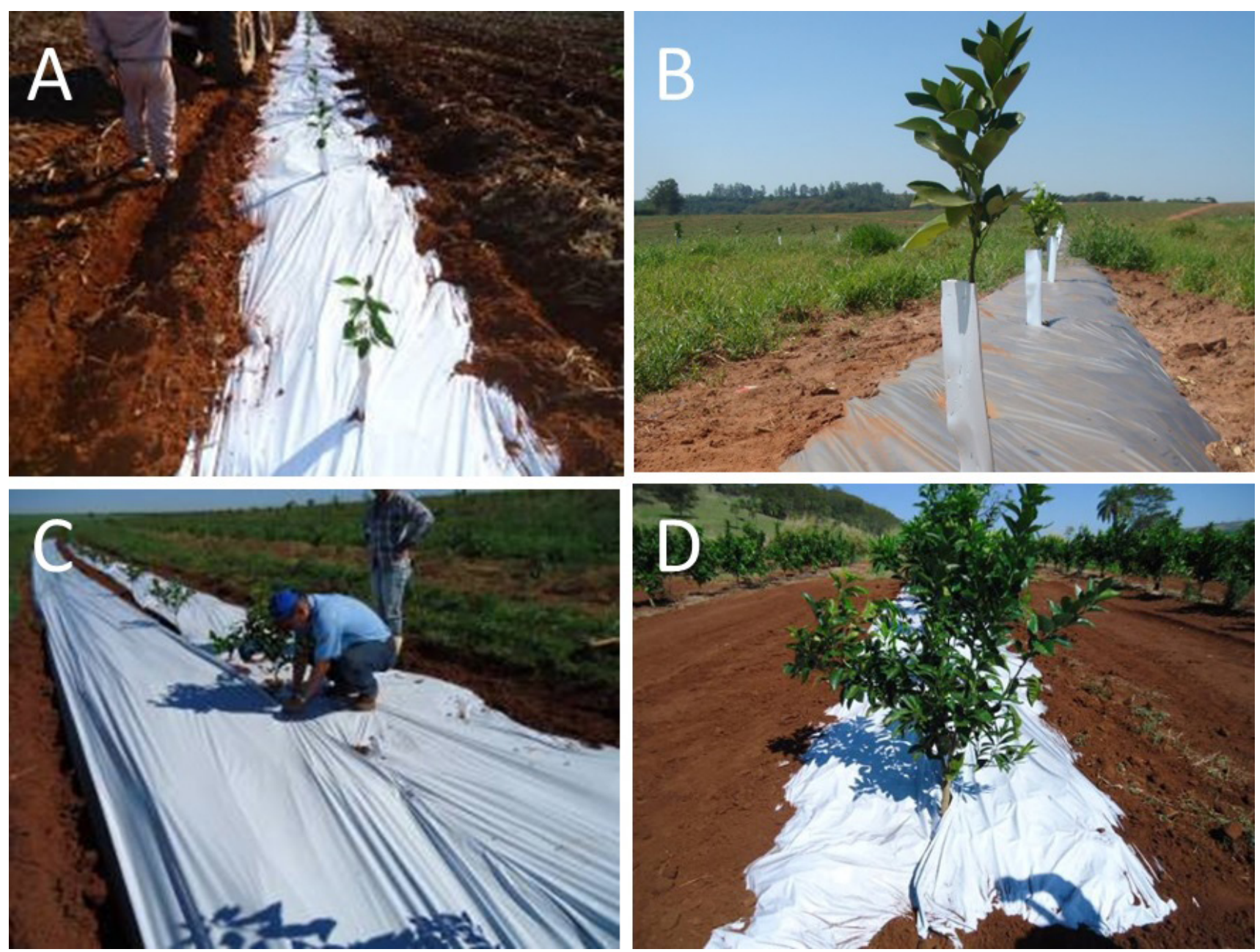

Figure 2. Installation of soil covers with white/black plastic films, single band, in newly planted sweet orange orchard (A); silver/black, single band in newly planted orchard (B), white/black, double band in a three-month-old orchard (C); white/black, double band in 19-month-old orchard (D).

Variables evaluated in the five experiments were: height $(\mathrm{H})(\mathrm{cm})$ and canopy diameter $(\mathrm{cm})$ of trees, measured with graduated ruler, and measurements were performed from 6 to 28 months after plastic film cover application at intervals from 3 to 5 months, depending on the experiment; tree trunk diameter $(\mathrm{mm})$, measured $2 \mathrm{~cm}$ above the grafting union with digital caliper from 12 to 39 months after plastic film cover application at intervals from 3 to 5 months, according to the experiment; and tree canopy volume $(\mathrm{V})\left(\mathrm{m}^{3}\right)$, calculated using the following equation: $\mathrm{V}=(2 / 3) \cdot\left(\pi \cdot \mathrm{R}^{2}\right) \cdot \mathrm{H}$ (MENDEL, 1956), where $\mathrm{R}$ is the canopy radius. Production ( $\mathrm{kg} /$ tree), measured by weighing the fruits harvested per tree in digital scale suspended from a hook, was evaluated in experiments (I), (II and III) and (V), in years 2014 to 2016, 2015 and 2012, respectively.

The experimental design, in the five experiments, was completely randomized. In experiment I, there were four plots per treatment, 227 trees per plot and 12 useful trees per evaluation; in experiment II, there were ten plots per treatment, 227 trees per plot and five useful trees per evaluation; in experiment III, there were ten plots per treatment, 227 trees per plot and five useful trees per evaluation; in experiment IV, there were four plots per treatment, 20 trees per plot and nine useful trees per evaluation; and in experiment $\mathrm{V}$, there were five plots per treatment, 47 trees per plot and seven useful trees per evaluation. Further information about treatments and procedures in each experiment is shown in Table 1.

Vegetative growth data were submitted to analysis of variance of repeated measures over time, considering the mixed linear model with random plot effect and fixed effect of time, treatment and interaction. Experiments were analyzed separately. The covariance structure was calculated using the plugin varIdent from the nlme package (PINHEIRO et al., 2020). After building the model, factors were analyzed using the Wald's F test $(p<0.05)$. When interaction effect or time effect was found, data were analyzed using polynomial regressions and the same procedure as the complete model; however, considering time as quantitative variable. In addition, within each time, contrast was performed using the Tukey's test ( $\mathrm{p} \leq 0.05)$, according to procedure of the emmeans package (LENTH et al., 2018). Results of production per tree were analyzed separately, by time and location, and when they were significant by analysis of variance $(\mathrm{p} \leq 0.05)$, averages 
were compared by the Tukey's test $(p \leq 0.05)$ when there were more than two treatments under evaluation. All procedures were performed with the R software (R Core Team, 2020).

\section{Results and discussion}

Regarding variables height, canopy diameter and volume, significance ( $\mathrm{p}$-value of Wald's $\mathrm{F}$ test of the deviance chart $<0.05$ ) was observed for the effects of treatment, time and treatment $x$ time interaction in the five experiments. For variable trunk diameter, all effects and interaction were also significant, except for treatment $\mathrm{x}$ time interaction in experiment $I(p=0.15)$ and treatment effect in experiment III $(p=0.06)$. This indicates that, in general, the vegetative growth of plants with plastic film cover was higher than that of plants without plastic cover and that the behavior of the growth curves was different over time.
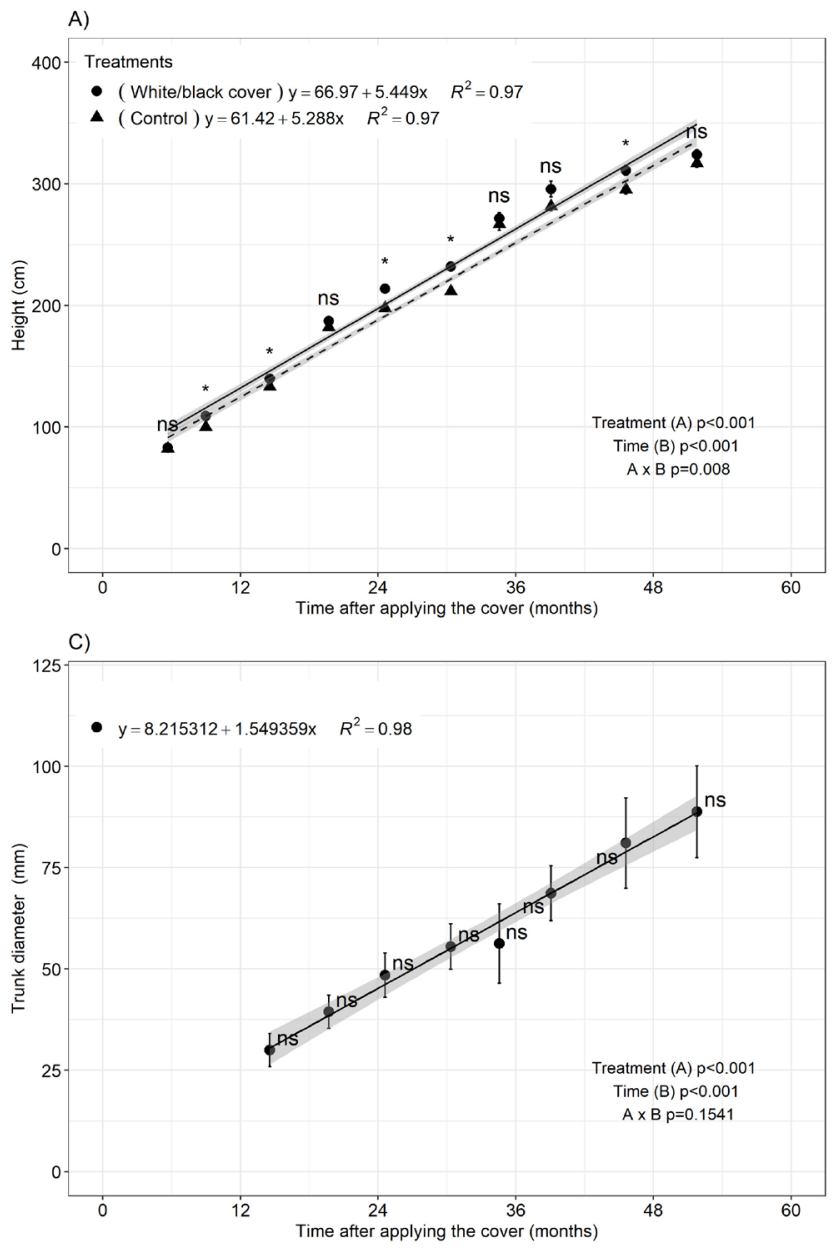

In experiment I, installed immediately after planting and in rainfed condition, trees with plastic film cover showed greater growth than trees without soil cover (Figure 3). After nine months of plastic cover application, significant differences were observed in canopy height and diameter of trees (Figures 3A and 3B). Until 30 months after soil cover application, trees with soil cover were, on average, $6 \%$ taller and with canopy diameter $13 \%$ wider than trees without soil cover. After this period, differences between treatments were minor or not significant. Regarding trunk diameter, significant differences were observed up to 25 months after soil cover application, when covered trees had, on average, trunk diameter $13 \%$ wider than trees without soil cover (Figure 3C). With regard to canopy volume, significant differences were observed 25 months after soil cover; however, the percentage difference decreased over time (Figure 3D). On average, trees with soil cover had canopy volume $13 \%$ higher.
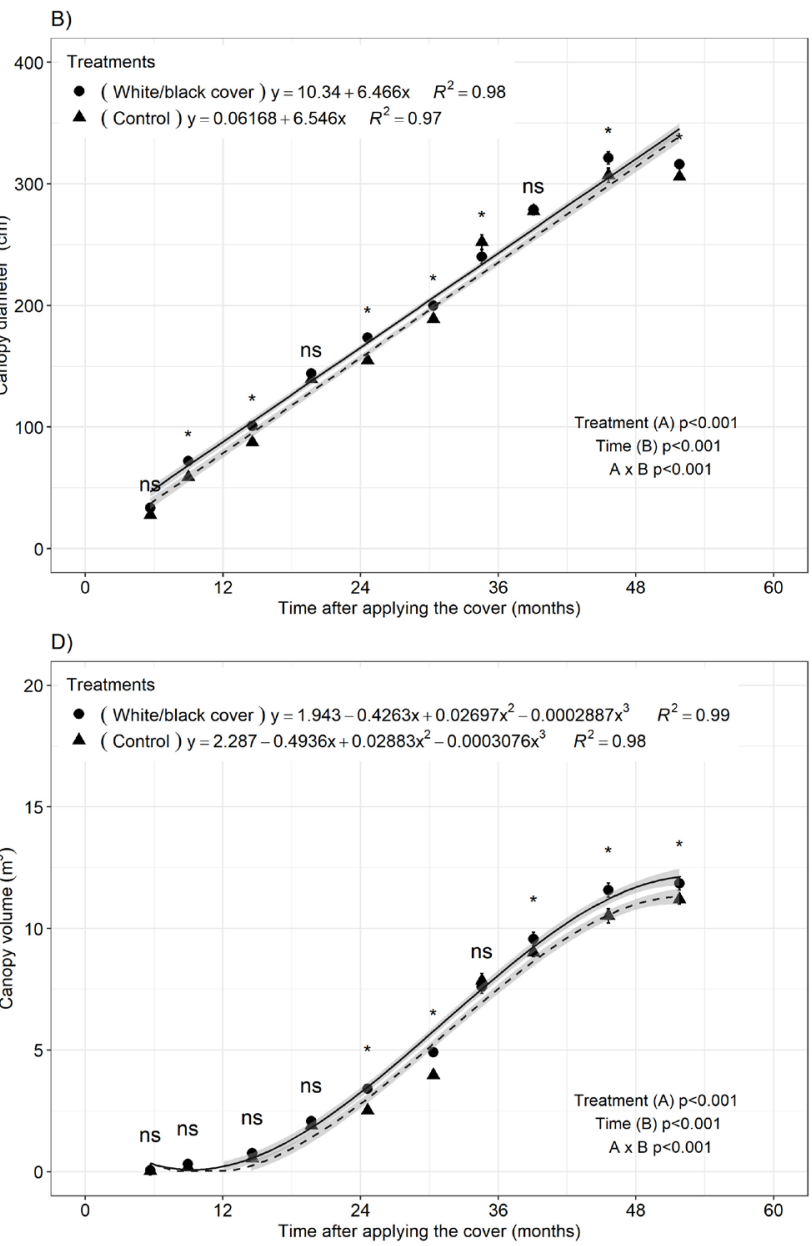

Figure 3. Height (A), canopy diameter (B), trunk diameter (C) and canopy volume (D) of 'Hamlin' sweet orange grafted on 'Swingle' citrumelo with and without plastic film cover applied shortly after planting in rainfed system in Gavião Peixoto/SP. * Treatments differ at 5\% significance. ${ }^{\text {ns }}$ Treatments do not differ at 5\% significance. 
In experiment II, installed shortly after planting and in rainfed condition, soil cover with silver/black or white/black plastic film induced greater height, canopy diameter and volume between 12 and 39 months after soil cover application (Figures 4A, 4B and 4D). Increments were greater for silver/black film than for white/black film, even though silver/black film had narrower band width. During this period, the average increase in height, canopy diameter and volume for silver/black film was
$12 \%, 15 \%$ and $33 \%$, respectively, while for white/black film, increases were $10 \%, 10 \%$ and $40 \%$, respectively. Similar pattern was observed for trunk diameter, but differences were significant up to 32 months after soil cover application. Trunk diameter increased by 4 and $8 \%$, respectively, in trees with white/black and silver/black plastic film in relation to control trees.
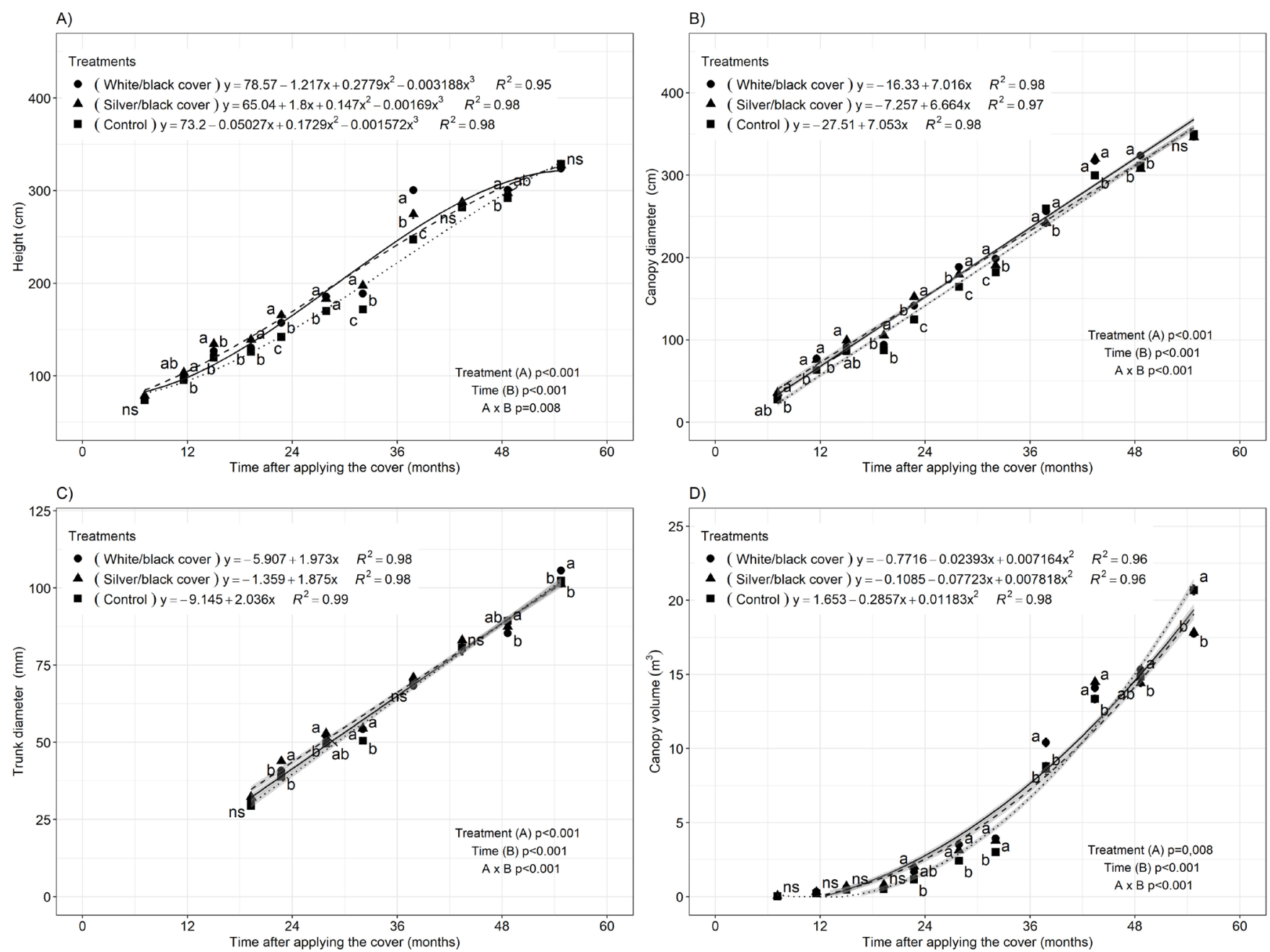

Figura 4. Height (A), canopy diameter (B), trunk diameter (C) and canopy volume (D) of 'Natal' sweet orange grafted on 'Swingle' citrumelo with and without plastic film cover applied shortly after planting in rainfed system, in Bariri/SP. ${ }^{\text {ns }}$ Treatments do not differ at $5 \%$ significance. Same letters within each time do not differ by the Tukey's test at $5 \%$ significance. 
On the other hand, in experiment III, installed shortly after planting in irrigated system, growth differences between trees with and without cover were smaller and, in most evaluations, not significant (Figure 5). On average, throughout the evaluation period, height, canopy diameter, trunk diameter and canopy volume were $5 \%, 2 \%, 1 \%$ and $10 \%$ higher, respectively, for white/black film and $3 \%, 1 \%, 2 \%$ and $5 \%$, respectively, for silver/black film in relation to control trees.

In experiment IV, installed three months after planting and under rainfed conditions, soil cover with white/black film induced, on average considering all evaluations, height, canopy diameter, trunk diameter and canopy volume $6 \%, 24 \%, 17 \%$ and $60 \%$ higher, respectively, in relation to trees without soil cover (Figure 6). As observed in experiments I and II, differences between treatments decreased significantly 34 months after plastic cover installation.

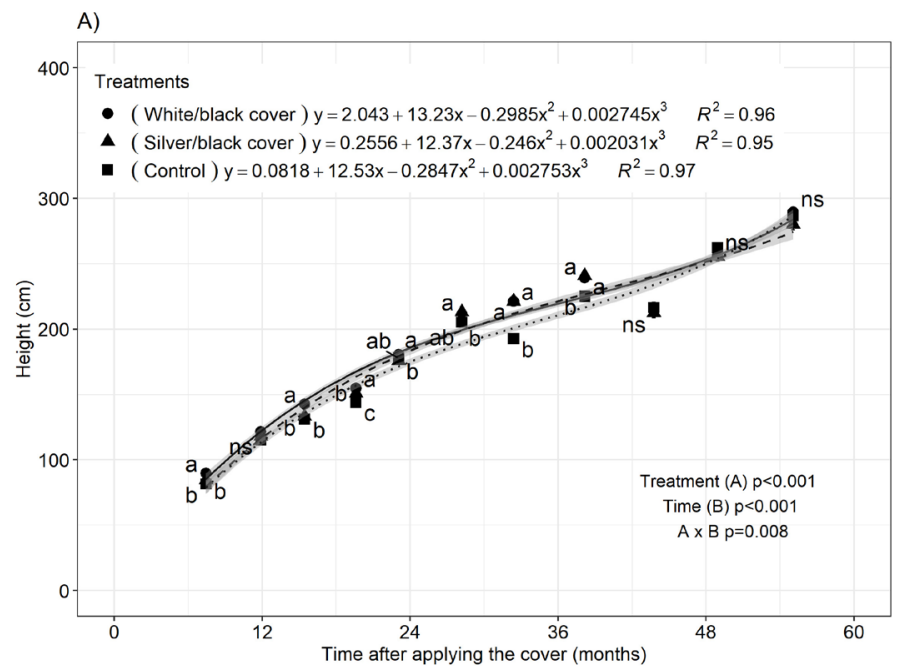

C)

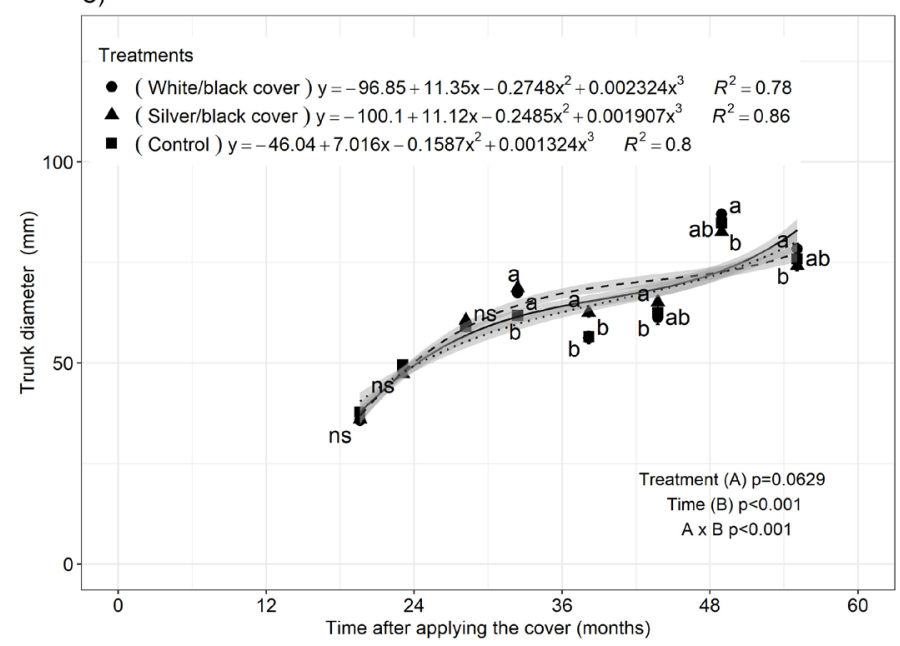

In experiment $\mathrm{V}$, installed 19 months after planting and in irrigated system, there was significant increase in height, canopy diameter and volume for trees with soil cover (Figures 7A, 7B and 7D), but not for trunk diameter (Figure 7C). From the third year of plastic film cover installation, differences reduced and became insignificant. Until 32 months of the beginning of this experiment, the average increase in tree height, canopy diameter, trunk diameter and canopy volume was $6 \%, 13 \%, 9 \%$ and $28 \%$, respectively, in relation to control trees.

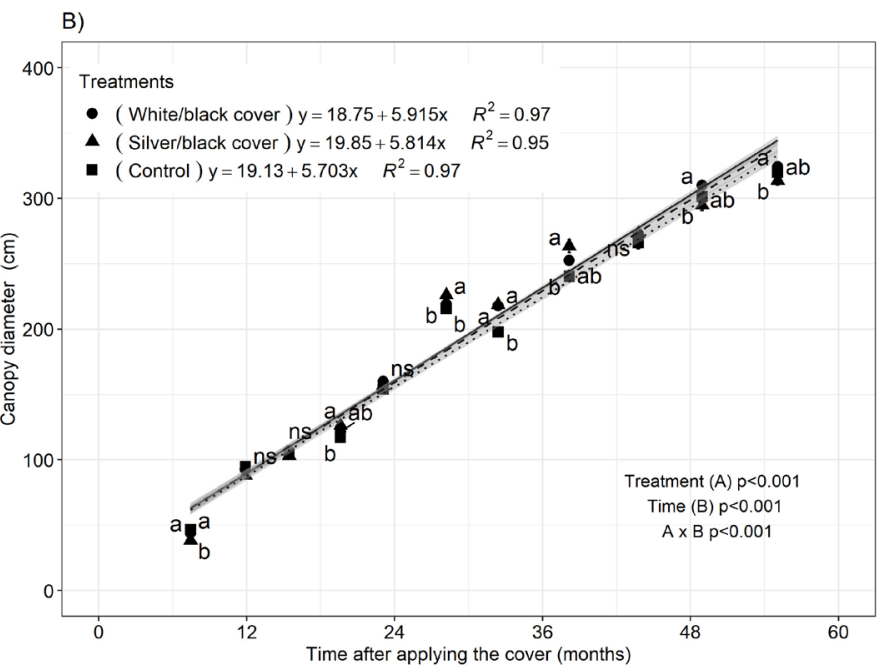

D)

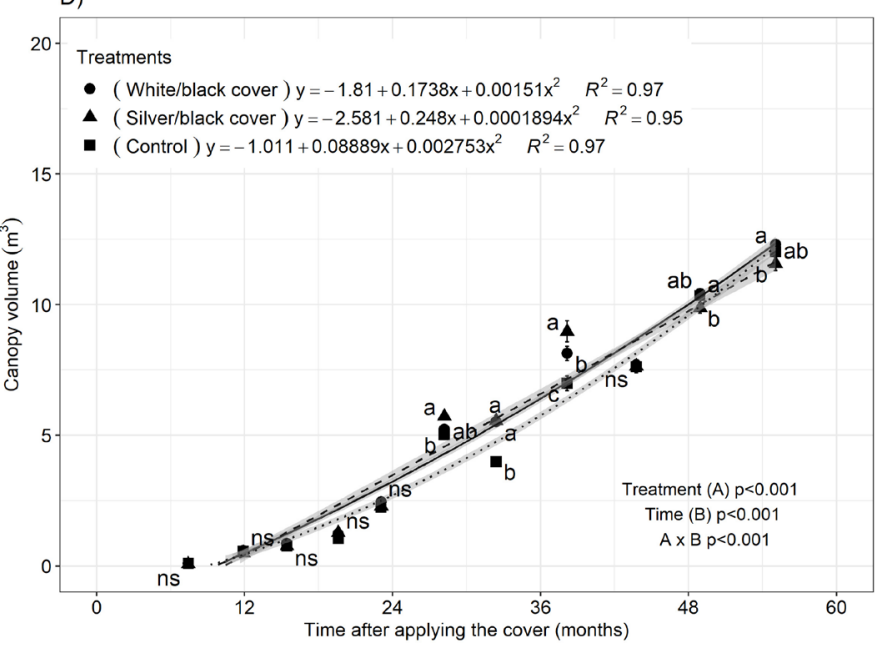

Figure 5. Height (A), canopy diameter (B), trunk diameter (C) and canopy volume (D) of 'Valencia' sweet orange grafted on 'Swingle' citrumelo with and without plastic film cover applied shortly after planting in irrigated system, in Bariri/SP. ${ }^{\text {ns }}$ Treatments do not differ at 5\% significance. Same letters within each time do not differ by the Tukey's test at 5\% significance. 

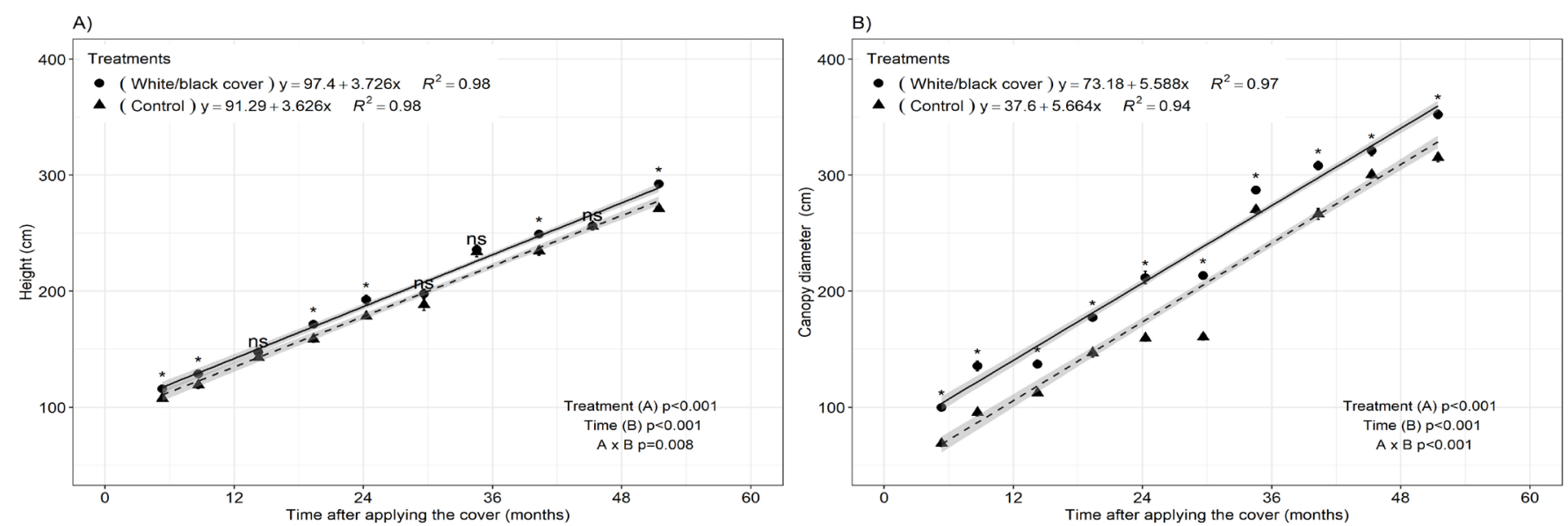

C)

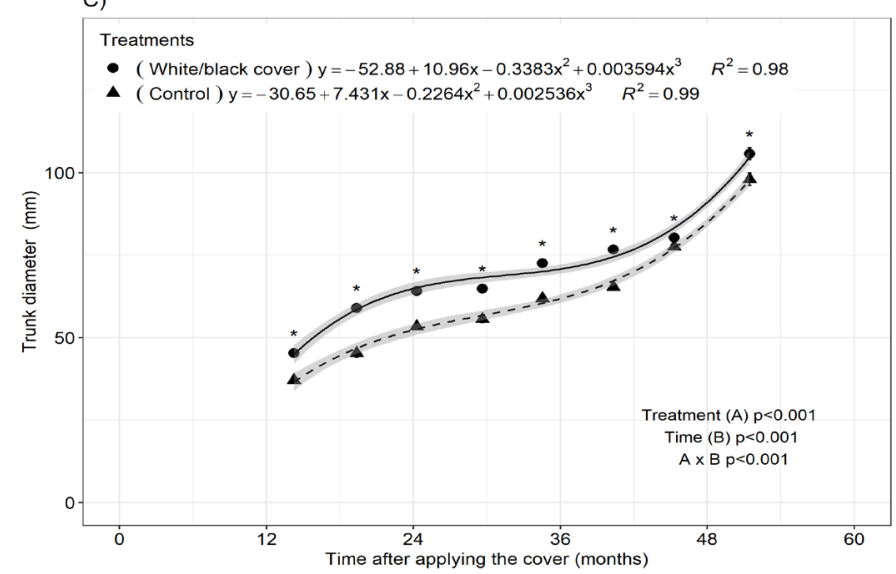

D)

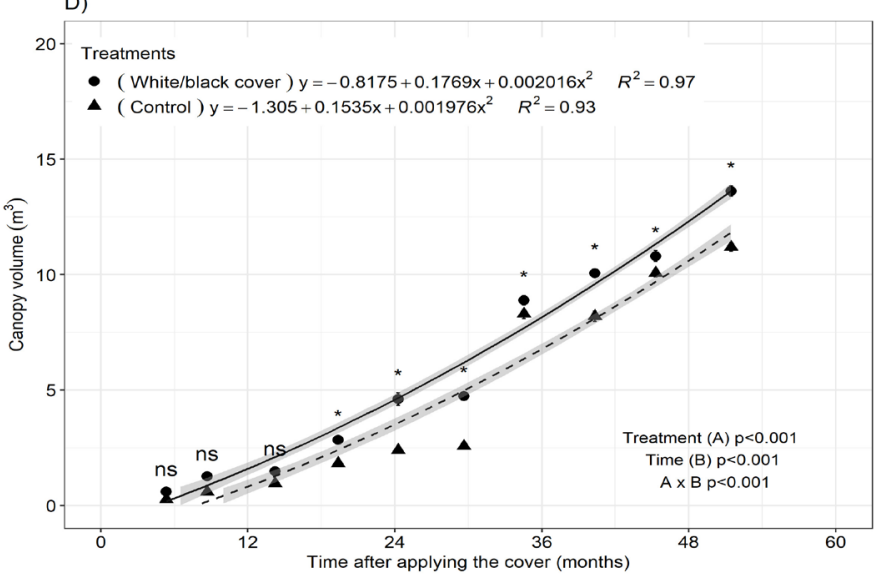

Figure 6. Height (A), canopy diameter (B), trunk diameter (C) and canopy volume (D) of 'Pera Rio' sweet orange grafted on 'Swingle' citrumelo with and without plastic film cover applied three months after planting in rainfed system, in Itápolis/SP. * Treatments differ at $5 \%$ significance. ${ }^{\text {ss }}$ Treatments do not differ at $5 \%$ significance.

In general, the positive effect of soil cover with plastic film in orchards was observed until approximately the end of the third year of cover installation. As trees grew and the plastic film degraded, differences in vegetative growth decreased and became insignificant between trees with and without plastic film cover.

Regarding fruit yield, in the different treatments, in the first harvest of experiment I, in Gavião Peixoto/ SP (second year after planting), trees with plastic film cover produced, on average, $50 \%$ less than those without plastic film cover; however, in the following year, there was an inversion, with trees with plastic film cover producing $25 \%$ more. In the third harvest (fourth year after planting), when part of the plastic film cover was already degraded, no difference in production between treatments was observed (Figure 8A). In Bariri/SP (third year after planting), in experiment III in irrigated system (Figure 8C), trees with and without plastic film cover did not show significant difference in production; however, in experiment II, in rainfed system, trees with plastic film cover produced, on average, $45 \%$ (white/black color) and $21 \%$ (silver/black color) more than control trees (Figure 8B). In experiment V, in Santa Rosa de Viterbo/SP, 12 months after plastic film cover application in the irrigated system, covered trees produced, on average, $41 \%$ more than control trees (Figure 8D). 

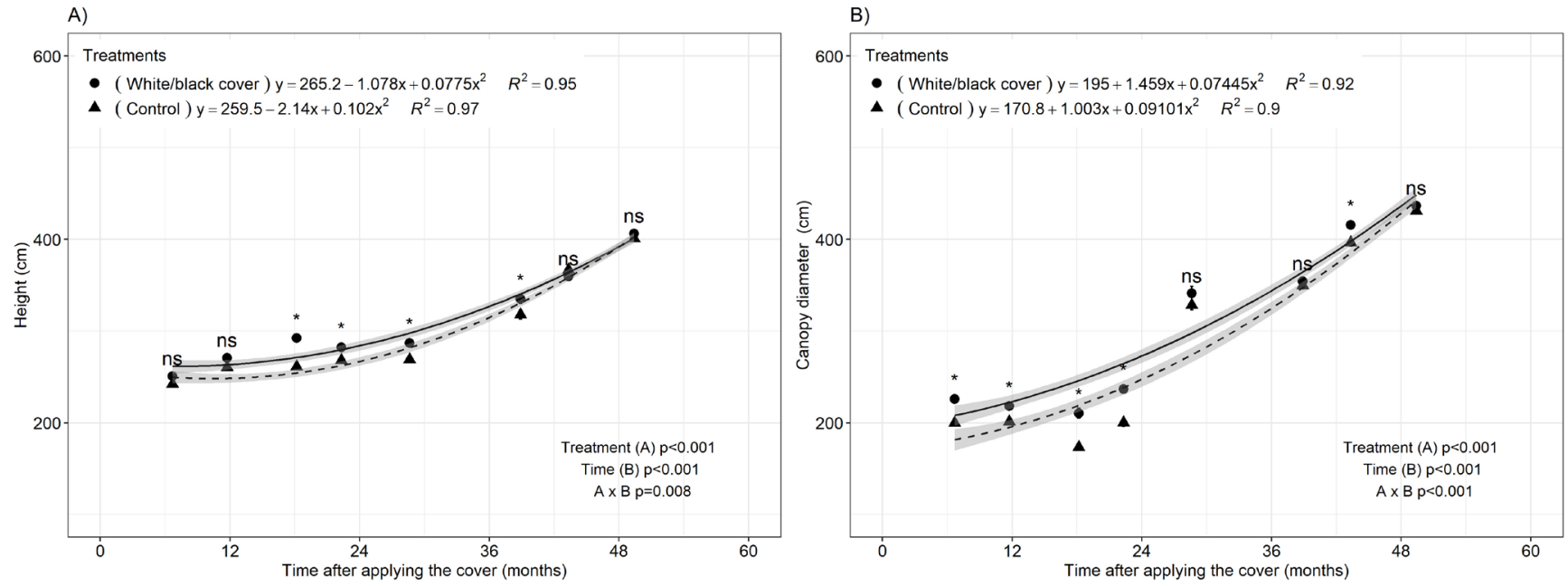

C)

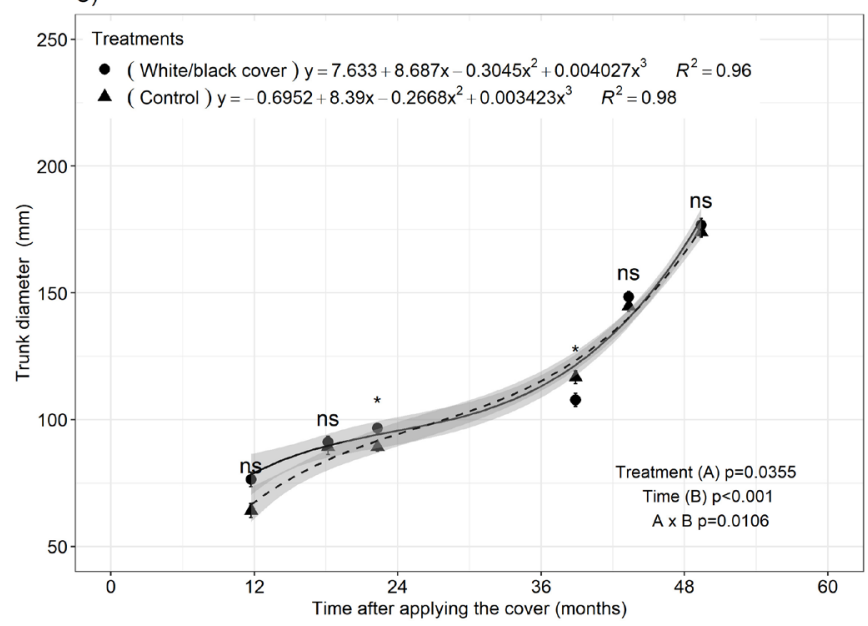

D)

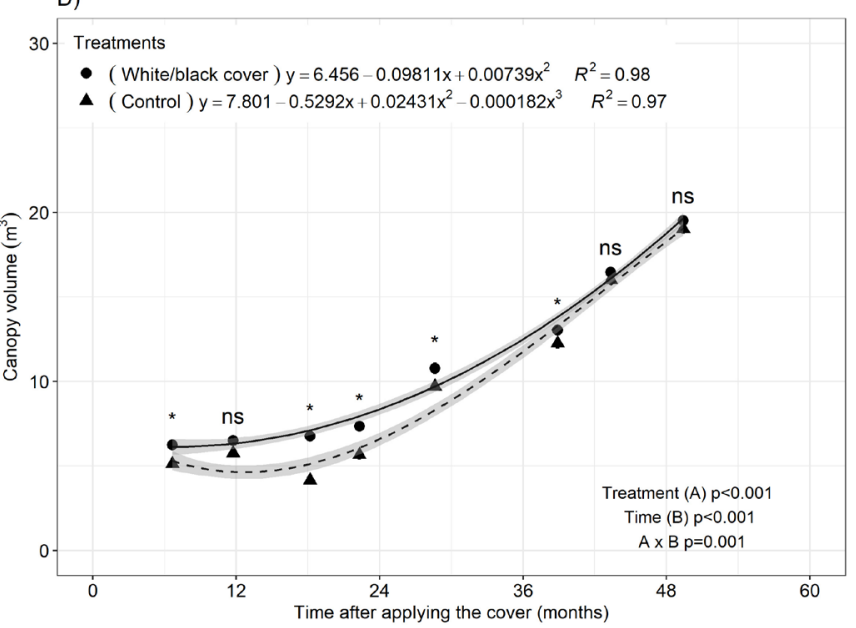

Figure 7. Height (A), canopy diameter (B), trunk diameter (C) and canopy volume (D) of 'Pera Rio' sweet orange grafted on 'Sunki' mandarin with and without plastic cover applied 19 months after planting in irrigated system, in Santa Rosa de Viterbo/SP. * Treatments differ at 5\% significance. ${ }^{\text {ns }}$ Treatments do not differ at 5\% significance.

Overall, the present study observed, until three years after plastic film cover application, significant differences in the vegetative growth of sweet orange trees. Such results are justified, since, according to Kaur; Bons (2017), Farias-Larios et al. (1996), Rajapakse; Kelly (1994) and Tindall et al. (1991), in order to accelerate its development, plants require solar radiation as an energy source to perform photosynthesis, higher soil temperature, increased availability and absorption of water and nutrients by roots and increased number and activity of soil microorganisms, which are all factors associated with the use of soil cover with plastic films.
Vegetative growth was higher both in rainfed (Gavião/SP and Itápolis/SP) and irrigated conditions (Santa Rosa de Viterbo/SP), except for Bariri/SP, where the vegetative growth of trees with film cover plastic was greater in rainfed conditions than in irrigated system. The use of plastic cover retains water for longer period in the soil and reduces evaporation losses. Consequently, there is reduction in water stress and better distribution of nutrients near the root zone, which was associated with better performance in young plants (GUZMÁN, 2020; ZHENG et al., 2017). In this management, soil cover is complete, contributing to more effective weed control (data not shown), which may have reduced competition for water and soil nutrients and benefited the growth of orange trees, as reported for 'Eureka' lemon (Citrus limon Burm) (KUMAR, 2014). 

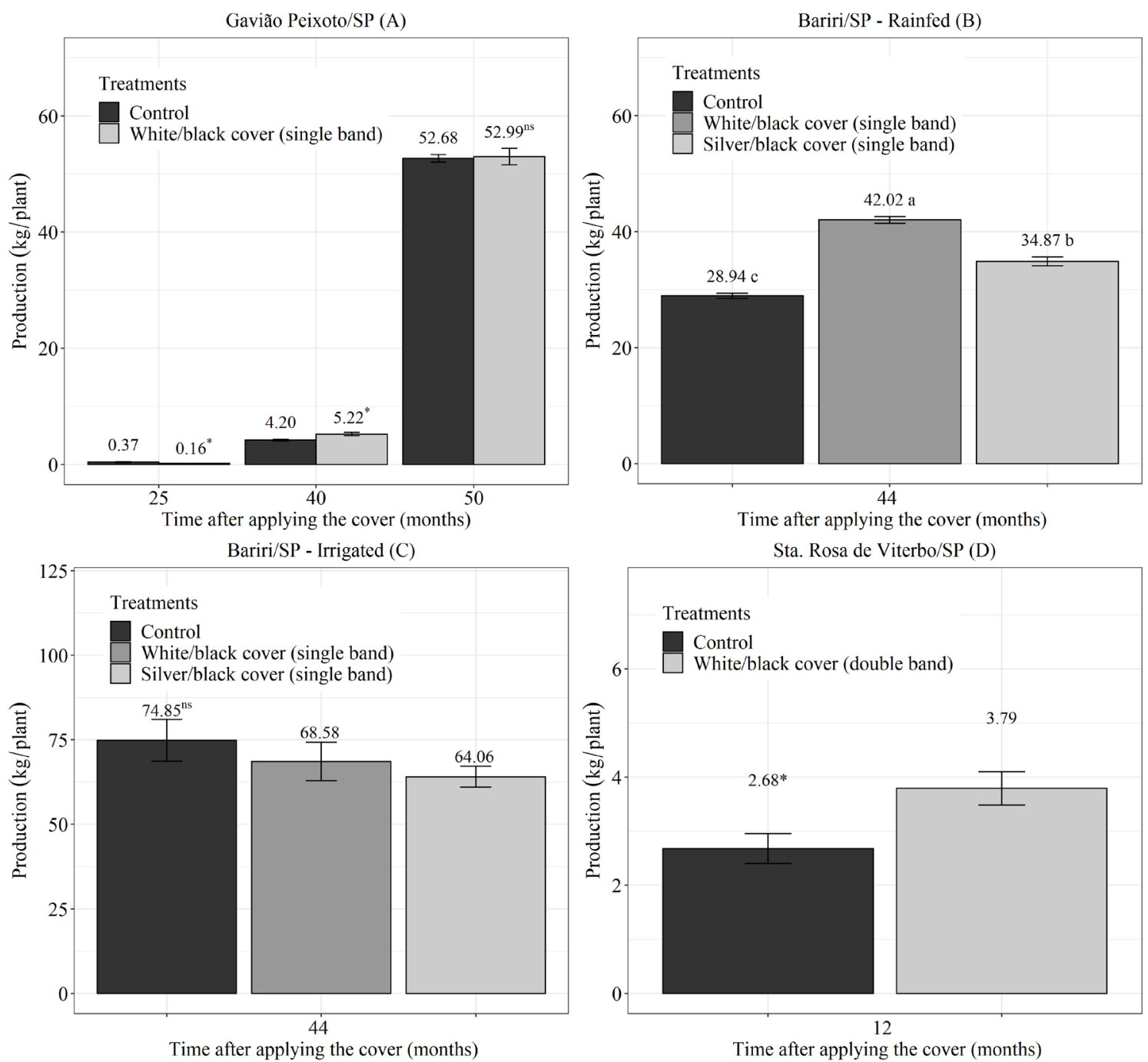

Figure 8. Fruit production ( $\mathrm{kg} /$ tree) of 'Hamlin' sweet orange grafted on 'Swingle' citrumelo with and without plastic film cover applied shortly after planting in rainfed system, in Gavião Peixoto/SP (A); 'Natal' sweet orange grafted on 'Swingle' citrumelo in rainfed system (B), and 'Valencia' sweet orange grafted on 'Swingle' citrumelo in irrigated system (C), with and without plastic film cover applied shortly after planting, in Bariri/SP; and 'Pera Rio' sweet orange grafted on 'Sunki' mandarin with and without plastic film cover applied 19 months after planting in irrigated system, in Santa Rosa de Viterbo/SP (D). * Treatments differ at 5\% significance. ${ }^{\text {ns }}$ Treatments do not differ at 5\% significance. In (B), means followed by different letters differ by the Tukey's test at $5 \%$ significance.

Only in one of the experiments in rainfed conditions, silver/black plastic film cover induced greater vegetative growth of trees compared to white/black plastic cover. There are often controversial reports on the effect of color or quality of plastic soil covers on plant development as a function of quality and quantity of radiation reflected on plants (LEE et al., 1996; DECOTEAU et al., 1988). Wang et al. (2019) found higher internal fruit quality of grapefruit $(C . \times$ paradisi Macfad.) when grown in soil covered with silver/black plastic film, being consistent with studies carried out by Jiang et al. (2013), Shi et al. (2011), Chen et al. (2010) and Liu et al. (2008). However, Kumar (2014) reported that black plastic cover is the most favorable to the growth and production of 'Eureka' lemon, when testing various soil covers (organic and inorganic) under rainfed conditions in India. Finally, Croxton et al. (2014) observed by the cross-sectional area of the trunk of sweet orange trees, greater growth of trees managed with metallized polyethylene cover, followed by uncovered soil and white cover, in addition to lower capture of Diaphorina citri in trees whose soil had reflective cover (metallized polyethylene), since it disorients the flight of psyllids, repelling them from sweet orange trees.

In this work, the initial production of sweet orange trees was similar or $20-45 \%$ higher with the use of plastic film. In fertigated lemon trees in India, the use of black plastic cover increased fruit production from 14.6 to $20.5 \%$ in relation to uncovered soil (PANKAJ \& RUMEE, 2014). In Weslaco, Texas/USA, grapefruit trees were submitted to different soil management systems and black plastic cover improved not only tree growth, but also fruit productivity (SIMPSON et al., 2020). It is also important to highlight that increases in vegetative growth and initial fruit production observed in this study due to the use of soil cover with plastic film compared to the absence of soil cover occurred under various scion and rootstock 
varieties, soil types and cultural practices (Table 1). In all locations, the rainfall pattern was similar during the assessment period (Figure 1), with average annual rainfall of Gavião Peixoto/SP equal to $1,214 \mathrm{~mm}$, Bariri/SP equal to $1,387 \mathrm{~mm}$, Itápolis equal to $1,008 \mathrm{~mm}$ and Santa Rosa de Viterbo/SP equal to $1,242 \mathrm{~mm}$. Irrigation was the factor that presented the most apparent effect. Even so, more in-depth studies investigating the relationships between different environments and management practices on the performance of plastic film covers should be carried out.

Taken together, the results of the present study suggest that soil cover with plastic film positively influences the initial growth of sweet orange trees under irrigated or rainfed conditions in the state of São Paulo, and may, in the short/medium term, increase initial crop production. However, despite the observed advantages, some problems still need to be resolved so that plastic soil cover can be used on a larger scale in citrus, among them the need for better soil preparation for cover application; the need for additional labor due to the difficulty of automating the operation for applying the plastic film cover either before or after citrus nursery trees planting; difficulty of supplying water and fertilizer to newly planted nursery trees under plastic film cover in orchards without drip irrigation/fertigation system; difficulty of handling weeds on the plastic edges and at cut points performed in the plastic film to coat citrus nursery trees; and the short durability of the plastic film cover in relation to citrus lifespan.

\section{Conclusions}

Soil cover with plastic film in the planting line has the potential to increase vegetative growth and fruit production of young sweet orange trees until the third year after application, especially in rainfed system under the conditions of the state of São Paulo.

\section{Acknowledgment}

To Fundecitrus for the financial support.

\section{References}

BASSANEZI, R.B. Evolución de la severidad y el daño de Huanglongbing en plantaciones de naranjo dulce y sus implicaciones para el manejo de la enfermedad. Cítricos en las Américas, v.1, p.31-44, 2018.

BASSANEZI, R.B.; SILVA JUNIOR, G.J.; FEICHTENBERGER, E.; BELASQUE JÚNIOR, J.; BEHLAU, F.; WULFF, N.A. Doenças dos Citros. In: AMORIM, L.; REZENDE, J.A.M.; BERGAMIN FILHO, A.; CAMARGO, L.E.A. (org.). Manual de fitopatologia: doenças das plantas cultivadas. 5.ed. Ouro Fino: Editora Agronômica Ceres, 2016. v.2, p.271-306.

CARVALHO, S.A.; GIRARDI, E.A.; MOURÃO FILHO, F.A.A.; FERRAREZI, R.S.; COLETTA FILHO, H.D. Advances in citrus propagation in Brazil. Revista Brasileira de Fruticultura, Jaboticabal, v.41, n.6, e-422, 2019.

CHEN, F.X.; LIU, X.H.; WU, D.Y.; CHEN, L.S. Reflecting film mulch around tree trunks reduces acidity of loquat ripe fruit. Acta Horticulturae Sinica, Berijing, v.37, n.11, p.1836-1842, 2010.

COLETTA-FILHO, H.D.; TARGON, M.L.P.N.; TAKITA, M.A.; DE NEGRI, J.D.; POMPEU JUNIOR, J.; MACHADO, M.A. First report of the causal agent of Huanglongbing ('Candidatus Liberibacter asiaticus') in Brazil. Plant Disease, St Paul, v.88, p.1382, 2004.

CROXTON, S.D.; STANSLY, P.A. Metalized polyethylene mulch to repel Asian citrus psyllid, slow spread of huanglongbing and improve growth of new citrus plantings. Pest Management Science, London, v.70, n.2, p.318-323, 2014.

DECOTEAU, D.R.; KASPERBAUER, M.J.; DANIELS, D.D.; HUNT, P.G. Plastic mulch colour effects on reflected light and tomato plant growth. Scientia Horticulturae, v.34, n.3-4, p.169-175, 1988.

DE NEGRI, J.D.; STUCHI, E.S.; BLASCO, E.E. Planejamento e implantação do pomar cítrico. In: MATTOS JUNIOR, D. de; DE NEGRI, J.D.; PIO, R.M.; POMPEU JUNIOR, J. (ed.). Citros. Campinas: Instituto Agronômico: Fundag, 2005. p.410-427.

FARIAS-LARIOS, J.; OROZCO, M.; GUZMAN, S.; PEREZ, J. Effect of plastic mulch, floating rowcovers and microtunnels on insect population and yield of muskmelon. HortScience, v.31, n.4, p.677b-677, 1996. 
GUZMÁN, S.M. Fabric mulch groundcovers save water. Citrus industry, Newberry, 2020. Disponível em: https://citrusindustry.net/2020/04/14/fabric-mulchgroundcovers-save-water/. Acesso em: 15 maio 2020.

GREER, L.; DOLE, J. M. Aluminum foil, aluminumpainted, plastic, and degradable mulches increase yields and decrease insect-vectored viral diseases of vegetables. HortTechnology. Alexandria, v.13, n.2, p.276-284, 2003.

JIANG, N.; JIN, L.F.; SILVA, J.A.T.; ISLAM, M.D.Z.; GAO, H.W.; LIU, Y.Z.; PENG, S.A. Activities of enzymes directly related with sucrose and citric acid metabolism in citrus fruit in response to soil plastic film mulch. Scientia Horticulturae, New York, v.168, p.73-80, 2014.

JIANG, N.; GAO, H.W.; JIN, L.F.; LIU, Y.Z.; PENG, S.A. The impact of plastic film mulching on citrus fruit sugar accumulation and sucrose metabolism-related enzymes. Scientia Agricultura Sinica, Beijing, v.46, n.2, p.317-324, 2013.

KASIRAJAN, S.; NGOUAJIO, M. Polyethylene and biodegradable mulches for agricultural applications: a review. Agronomy for Sustainable Development, Berlin, v.32, p.501-529, 2012.

KAUR, J.; BONS, H.K. Mulching: a viable option to increase productivity of field and fruit crops. Journal of Applied and Natural Science, Dallas, v.9, n.2, p.974982, 2017.

KUMAR, V. Effect of organic and inorganic mulches on soil-moisture retention, weed suppression, yield and economics of eureka lemon (Citrus limon Burm) under rainfed condition in shiwalik foothills of Himalayas. Journal of Soil and Water Conservation, Baltimore, v.13, n.4, p.313-317, 2014.

KUNINGA, T.; HOSHI, N.; KITA, M. Effect of reflective mulching sheets on citrus tree growth. Acta Horticulturae, The Hague, v.1252, p.65-270, 2019.

LEE, G.H.; BUNN, J.M.; HAN, Y.J.; DECOTEAU, D.R. Determination of optimum levels of light irradiation needed to control ripeniung of tomatoes. Transactions of the ASAE, v. 39, n. 1, p. 169-175, 1996.

LENTH, R.; SINGMANN, H.; LOVE, J,; BUERKNER, P.; HERVE, M. Estimated marginal means, aka leastsquares means. In: R package version, v.1, n.1,3, 2018.
LIU, L.; XU, X.F.; WANG, Y.; LI, T.L.; HAN, Z.H. Effect of different reflecting films on berry quality and sucrose metabolism of grape in greenhouse. Journal of Fruit Science, Zhengzhou, v.25, n.2, p.178-181, 2008.

MATTOS JR, D.; DE NEGRI, J.D.; POMPEU JR, J.; GHILARDI, A.A.; AZEVEDO, F.A.; BASTIANEL, M. Citros Principais informações e recomendações de cultivo. In: AGUIAR, A.T.E.; GONÇALVES, C.; PATERNIANI, M.E.A.G.Z.; TUCCI, M.L.S.; CASTRO, C.E.F. Instruções agrícolas para as principais culturas econômicas 7.ed. Campinas: Instituto Agronômico, 2014. p.140-149. (Boletim, 200).

MENDEL, K. Rootstock-scion relationships in Shamouti trees on light soil. Ktavim, Rehovot, v.6, p.35-60, 1956.

PANKAJ, B.; RUMEE, H. Studies on fertigation and soil application methods alongwith mulching on yield and quality of Assam lemon (Citrus limon L. Burmf.). Indian Journal of Horticulture, New Delhi, v.71, n.2, p.190-196, 2014.

PINHEIRO, J.; BATES, D.; DEBROY, S.; SARKAR, D.; HEISTERKAMP, S.; VAN WILLIGEN, B.; MAINTAINER, R. The Nlme Package: Linear and nonlinear mixed effects models. $\mathrm{R}$ version, 3. (1). $\mathrm{R}$ package version, 2017.

RAJAPAKSE, N.C., KELLY, J.W. Problems of reporting spectral quality and interpreting phytochrome-mediated response. HortScience, v.29, n. 12, p.1404-1407, 1994.

ROLIM, G.S.; CAMARGO, M.B.P.; LANIA, D.G.; MORAES, J.F.L. Classificação climática de Köppen e de Thornthwaite e sua aplicabilidade na determinação de zonas agroclimáticas para o estado de São Paulo. Bragantia, Campinas, v.66, n.4, p.711-720, 2007.

ROSSI, M. Mapa pedológico do Estado de São Paulo: revisado e ampliado. São Paulo: Instituto Florestal, 2017. $118 \mathrm{p}$.

SETZER, J. Atlas climático e ecológico do Estado de São Paulo. Dourados: Comissão Interestadual da Bacia Paraná-Uruguai, 1966. 61p.

SHI, X.G.; CHEN, J.W.; XU, H.X.; LIU, C.R.; ZHENG, J.C.; WU, H.; XIE, M. Effects of vapor-permeable reflective film mulch on fruit quality of Ponkan tangerine. Journal of Fruit Science, Zhengzhou, v.28, n.3, p.418 422, 2011. 
SHIMAZAKI, M.; NESUMI, H. A Method for highquality citrus production using drip fertigation and plastic sheet mulching. Japan Agricultural Research Quarterly, Ibaraki, v.50, n.4, p.301-306, 2016.

SIMPSON, C.R.; GONZALES III, J.; ENCISO, J.; NELSON, S.D.; SÉTAMOU, M. Root distribution and seasonal fluctuations under different grove floor management systems in citrus. Scientia Horticulturae, New York, v.272, p.1-10, 2020.

TARARA, J.M. Microclimate modification with plastic mulch. HortScience, Alexandria, v.35, n.2, p.169-180, 2000 .

TINDALL, J.A.; BEVERLY, R.B.; RADCLIFFE, D.E. Mulch effect on soil properties and tomato growth using micro-irrigation. Agronomy Journal, v.83, n. 6, p.10281034, 1991.
VALDA LAUGALE, V.; LEPSE, L.; STRAUTINA, S.; KRASNOVA, I.; SEGLINA, D. Effect of planting density and plastic soil mulch on strawberry plant development, yield and fruit quality. Acta Horticulturae, The Hague, v.926, p.517-523, 2012.

WANG, Y.; FU, X.; HE, W.; CHEN, Q.; WANG, X. Effect of Plastic Film Mulching on Fruit Quality of Citrus grandis cv. 'Hongroumiyou' and ' Sanhongmiyou'. IOP Conference Series: Earth and Enviromental Science, Bristol, v.358, 2019.

ZHENG, W.; WEN, M.; ZHAO, Z.; LIU, J.; WANG, Z.; ZHAI, B.; LI, Z. Black plastic mulch combined with summer cover crop increases the yield and water use efficiency of apple tree on the rainfed Loess Plateau. PloS ONE, San Francisco, v.12, n.9, e0185705, 2017. 